\title{
Decolonizing political ecology: ontology, technology and 'critical' enchantment
}

\author{
Karsten A. Schulz ${ }^{1}$ \\ University of Trier, Germany
}

\begin{abstract}
Current debates about the Anthropocene have sparked renewed interest in the relationship between ecology, technology, and coloniality. How do humans relate to one another, to the living environment, and to their material or technological artifacts; and how are these relations structured by coloniality, defined not only as a material process of appropriation and subjugation, but also as an exclusionary hierarchy of knowing and being that still pervades contemporary life? While these questions have of course received attention in decolonial theory, they have also captured the interest of scholars who self-identify with the field of political ecology. However, it can be argued that political ecology still primarily adheres to research practices and paradigms that have been developed in the West, regardless of its diversity and dynamism as a field of research. It is therefore suggested that a rapprochement between decolonial theory and political ecology can open up new perspectives on current debates that are emerging around the concept of the Anthropocene. In particular, the article takes the recent interest in the ontological implications of the Anthropocene as a point of departure to bring the decolonial notion of 'border thinking' into a conversation with the so-called 'new materialism' in political ecology. While both approaches are not necessarily opposed to values grounded in rationality, they can be seen as attempts to rethink ontological divisions such as human/nature or subject/object based on 'enchanted' ways of knowing and being-in-the-world. Yet, although enchantment has the potential to counter inherently colonial practices of appropriation, commodification and objectification, it is argued that keeping a moderately critical distance to enchanted narratives is still recommended, not because of the alleged naïveté of such narratives, but rather because enchantments may also function as and through technologies of power.
\end{abstract}

Key words: Anthropocene; political ecology; decoloniality; new materialism; border thinking; ontology; enchantment

\section{Résumé}

Les débats récents sur l'anthropocène soulignent un nouveau intérêt scientifique pour les relations complexes entre la écologie, la technologie, et le colonialisme. Comment est-ce que l'humanité se rapportent les uns envers les autres, à leur milieu de vie et à leurs objets physiques et techniques, et comment ces relations sont-ils structurées par le colonialisme, non seulement définies comme un processus matériel de l'appropriation et de l'assujettissement, mais aussi comme une hiérarchie d'exclusion de la connaissance et de l'être, qui imprègne encore la vie contemporaine? Bien que ces questions étaient naturellement traitées dans la théorie de la décolonialisme, ils ont également suscité l'intérêt des scientifiques, qui se disent les écologistes politiques. Néanmoins, on peut affirmer que l'écologie politique suivie encore des pratiques et paradigmes de recherche occidentaux, mais il est un domaine diversifié de la recherche. Il est donc proposé qu'un rapprochement entre la théorie décolonial et l'écologie politique peut ouvrir une nouvelle perspective sur les débats autour de l'anthropocène. Avant tout, cet article prend l'intérêt récent pour les implications ontologiques de l'anthropocène comme point de départ pour amener la notion décolonial de la «pensée frontalière» dans une conversation avec le soi-disant «nouveau matérialisme» dans l'écologie politique. Bien que les deux approches ne sont pas nécessairement opposés à des valeurs fondées sur la rationalité, ce sont des tentatives de reconsidérer les divisions ontologiques entre l'homme et la nature ou entre sujet et objet basé sur les moyens «enchantés» de savoir et d'être-dans-le-monde. Pourtant, bien que l'enchantement a le potentiel pour contrer les pratiques coloniales d'appropriation, de la marchandisation et de l'objectivation, il est soutenu que garder une distance

\footnotetext{
${ }^{1}$ Karsten A. Schulz, Postdoctoral Researcher, Governance and Sustainability Lab, Faculty of Regional and Environmental Sciences, University of Trier, Behringstraße 21, 54286 Trier, Germany. Email: schulzk "at" uni-trier.de. I would like to extend my sincere gratitude to Aram Ziai, Joshua Kwesi Aikins, James Cowan, Antje Bruns, Sebastian Weier, Rapti Siriwardane and Philipp Altmann for their valuable feedback on earlier drafts of this article. Moreover, I wish to cordially thank Simon Batterbury and the two anonymous reviewers of JPE. This article has benefitted considerably from their comments. All remaining errors are my own.
} 
critique aux récits enchantées est recommandé, pas à cause de la naïveté présumée de ces récits, mais plutôt parce que enchantements peut également fonctionner comme et grâce à des technologies du pouvoir.

Mots clés: Anthropocène; écologie politique; décolonialisme; nouveau matérialisme; pensée frontalière; ontologie; enchantement

\section{Resumen}

Recientes debates académicos sobre el Antropoceno apuntan hacia un renovado interés académico en las complejas relaciones entre la ecología, la tecnología y la colonialidad. ¿De qué manera los seres humanos se relacionan entre sí, de las condiciones de vida y de sus materiales o tecnológicos artefactos, y cómo son estas relaciones estructuradas por la colonialidad, que se define no sólo como un proceso material de la apropiación y el sometimiento, sino también como una jerarquía de exclusión del conocimiento y ser, que todavía impregna la vida contemporánea? Si bien estas cuestiones fueron tratadas por supuesto en la teoría decolonial, sino que también han atraído el interés de los científicos que se llaman ecologistas políticos. Sin embargo, se puede argumentar que la ecología política siguió siendo prácticas de investigación y paradigmas occidentales, aunque hay un amplio campo de investigación. Por lo tanto, se sugiere que un acercamiento entre la teoría decolonial y la ecología política puede abrir nuevas perspectivas sobre los debates actuales que están surgiendo en torno al concepto del Antropoceno. En particular, el artículo toma el reciente interés en las implicaciones ontológicas del Antropoceno como un punto de partida para que la noción decolonial de 'pensamiento fronterizo' en una conversación con el llamado 'nuevo materialismo' en la ecología política. Si bien ambos enfoques no son necesariamente opuestos a los valores fundados en la racionalidad, que pueden verse como intentos de replantear divisiones ontológicas entre los humanos y la naturaleza o entre sujeto y objeto en función de maneras 'encantadas' de conocer y de ser-en-el-mundo. Sin embargo, a pesar de encantamiento puede servir como un medio útil para contrarrestar las prácticas destructivas de apropiación, la cosificación y mercantilización, se argumenta que una distancia moderadamente crítico para narrativas encantada es recomendable, no es principalmente debido a la supuesta ingenuidad de estas narrativas, sino más bien porque encantamientos también podría funcionar como tecnologías de poder, y por medio de tecnologías de poder.

Palabras clave: Antropoceno; ecología política; decolonialidad; ontología; nuevo materialismo; pensamiento fronterizo; encantamiento

\section{The new human age}

Disbelief in the metaphysical logically results in misplacing the emphasis on the earthly. Our century, indeed, lives in the delusion that it is thereby preparing the golden age.

Carl Du Prel, The Philosophy of Mysticism, London 1889.

Modern man, the world eater, respects no space and no thing green or furred as sacred. The march of the machines has entered his blood. They are his seed boxes, his potential wings and guidance systems on the far roads of the universe ... The ancestral center exists no longer. Anonymous millions roam the streets.

Loren Eiseley, The Invisible Pyramid, New York 1970.

Drawing on mounting evidence for a profoundly negative human influence on the biological, chemical and geological processes on Earth, the atmospheric chemist Paul J. Crutzen and the ecologist Eugene F. Stoermer suggested in 2000 that a new geological epoch should be added to the geological timescale, the socalled Anthropocene (Crutzen and Stoermer 2000). As a potential successor of the current Holocene epoch that has now lasted for approximately 11,700 years, the Anthropocene concept describes a transition to a postHolocene world, in which human activities have shifted the Earth system toward a critical "no-analogue state" (Crutzen and Steffen 2003: 253). Due to the far-reaching implications of this major scientific proposal, a decision on whether the Anthropocene should be officially recognized as a period, epoch, or age in the geological timescale has yet to be made by the International Commission on Stratigraphy. However, once the 
concept of the Anthropocene had been introduced into academic debates, critics were quick to note that the 'New Human Age' is not only hard to grasp from a geological point of view, but also greatly contested from a cultural perspective. ${ }^{2}$ Is it the First Industrial Revolution and invention of the stream engine that marks the beginning of the Anthropocene (Steffen et al. 2015)? Is it the invention of agriculture approximately 8,000 BC that sparked a new epoch (Ruddiman 2013)? Or, did the Anthropocene begin with the Trinity test, the first explosion of an atomic bomb in July 1945, when, to paraphrase J.R. Oppenheimer's famous quote from the Bhagavad Gita, techno-scientific progress became "Death, the destroyer of worlds"? ${ }^{3}$

What is clear so far is that the proclamation of the Anthropocene- the symbolic epoch of reckoning that describes 'our' collective human actions as a geological force - has vividly dispelled the prevalent myths of techno-scientific optimism and linear economic progress. Debates about the implications of the Anthropocene continue across a wealth of disciplines that range from the natural sciences to the environmental social sciences and humanities (Castree 2015; Haraway et al. 2016; Lövbrand et al. 2015). At the heart of this ongoing conversation is the collective attempt to understand better the complex entanglements between Nature and Society in the twenty-first century, all while being faced with the politicized notion of a looming climate apocalypse, the "Sixth Mass Extinction Event, caused by humans" (Morton 2014: 258; Swyngedouw 2011). This apocalyptic notion of a human-induced mass extinction is precisely politicized, because it is rather unclear what it means to be 'human' in the so-called Anthropocene. Is it not astounding that the proposed new epoch which is meant to serve as a warning against anthropocentric hubris, should, of all things, carry the name of our species? Are we humans not willing to realize that we will hardly remain a "dominating force in the Earth System" for a very long time, unless we are able to arrest our innate capacity for self-destruction (Oldfield et al. 2014: 4)? Besides acting as a geological force that is destroying the planet and extinguishing other species, as the dominant narrative of the Anthropocene suggests, the human species also appears to be on the verge of destroying itself, while the planet will most likely endure.

Being confronted with such apocalyptic visions of a "bad Anthropocene" (Dalby 2016: 34), it certainly seems troubling that mainstream sustainability debates continue to be dominated by a strict separation between science and the political, a separation that is increasingly difficult to uphold (Latour and Davis 2015: 44). Not only are the predicaments of climate change and the Anthropocene essentially cultural and political in nature. They are closely linked to the material outcomes of a reflexive modernity, driven by the ethos of economic growth and linear techno-scientific progress. As Simon Dalby puts it, "political economy is now too a matter of political ecology, or at the planetary scale perhaps now a matter better understood in terms of political geoecology" (Dalby 2016: 34). Nevertheless, resilience theory and the "integrative super-discipline" of Earth System Science have been unsuccessful so far in facilitating a meaningful dialogue on Anthropocene matters between natural and social scientists (Pitman 2005: 137; Rickards 2015). Some observers have attributed this failed attempt to a lack of engagement with core social science concepts such as agency, knowledge, norms and power, together with unifying and normative-prescriptive ambitions that tend to countervail pluralist views of epistemology and ontology (Olsson et al. 2015; Schulz and Siriwardane 2015). ${ }^{4}$

In response to the conceptual limitations and apolitical tendencies of complexity science and resilience thinking, a number of scholars have offered alternative explanatory concepts such as the "Capitalocene" (Moore 2015b), the "Technocene" (Hornborg 2015), the "Chthulhucene" (Haraway and Kenny 2015), or the "anthroobscene" (Ernstson and Swyngedouw 2015) to describe the unjust and unsustainable patterns of industrialized production and consumption that mark today's contested political ecologies. Common to these perspectives is the realization that a fundamental shift in the Earth System, which is at the heart of the Anthropocene concept, arguably requires an equally fundamental shift in our understanding of the human condition and its symbiotic intersections with nature, society and technology.

\footnotetext{
2 'Anthropocene' from Greek: őv $\theta \rho \omega \pi \mathrm{o} \varsigma$ human being/man, $\kappa \alpha$ vó $\varsigma=$ new.

${ }^{3}$ Original footage of the interview with J.R. Oppenheimer can be accessed via this link.

${ }^{4}$ The term epistemology describes any specific theory about the nature of knowledge and justified belief. Ontology refers to a particular theory about the nature of being and reality (see Stanford Encyclopedia of Philosophy).
} 


\section{Epistemic decolonization and 'anthro-politics'}

As previously mentioned, one of the key conundrums of the ongoing Anthropocene discussion is the elusive notion of the anthropos itself. What does it mean to be 'human' in today's world? Considering the fossilfueled vision of an "Anthropocene Noir" (Rose 2013), where the seemingly abstract and yet frighteningly real entirety of humanity is facing its own consumptive death drive, it must be asked whether the imagined 'we' of 'humanity' really includes all of us in the same manner? Are 'all of us' equally responsible for dangerous anthropogenic changes to the Earth system? Who or what is included or excluded when notions of a shared humanity are invoked? In many ways, it has become apparent that illusions of limitless capitalist accumulation and lasting human dominion over nature have created a situation in which:

...the mixed effects of climate change will likely be distributed along the fracture lines of inequality - people in Canada, Europe, Australia, and the United States being the prime beneficiaries of new agricultural opportunities and access to natural resources; those in much of Africa, South Asia, Southeast Asia, Central America, and small island states finding themselves facing a barrage of storms, droughts, heat waves, and microbial invaders (Matthew 2008: 4; emphasis added).

Bearing in mind the unequally distributed effects of dangerous anthropogenic changes to the Earth's ecosystems, as well as different degrees of responsibility for the emergence of such threads, it has become increasingly clear that the undifferentiated concept of "humanity as a geological force" (Dalby 2016: 35) is inadequate to describe the politics and inequities of capitalist development. A long history of violence, racism and discrimination that is related to western industrialization and colonial appropriation is certainly testament to the fact that not all humans always count as human, and that animals and the environment often count as mere things. Simultaneously, it must be acknowledged that the historically instituted fracture lines of inequality which still pervade contemporary biosocial relations are not simply geographical and economic in nature. While the global North-South divide continues to be a highly influential concept for the analysis of geographical and economic power asymmetries, various lines of inequality are also drawn according to categories such as species, gender, race, class, or sexual orientation. Because of its apparent fixation on the species category of the human, the concept of the Anthropocene is therefore met with considerable skepticism, especially among indigenous scholars. ${ }^{5}$ Is the Anthropocene-related turn to ontology and its renewed focus on the category of being in fact equal to colonialism? Who participates in philosophical debates about who counts as human, and who does not? These critical questions are hardly surprising, considering the negative experiences of 'subaltern' populations with the so-called "colonial sciences", including anthropology and agronomy as well as area studies, history and ecology (Tilley 2011). Being mindful of the support that many-if not all—scientific disciplines have traditionally provided to the colonial enterprise of Empire, one can clearly see why knowledge production within academia still tends to reflect "heteropatriarchal and white supremacist structures that shape its current configurations and conversations" (Todd 2015: 247). Likewise, it is important to remember that epistemic and ontological hegemony coincide with the appropriation and reinterpretation of indigenous art, language and culture. Thus, being cognizant of the fact that the 'New Human Age' is to a large extent the historical product of colonial expansion, appropriation, and western industrialization, it seems worth examining what we may be able to learn from an engagement with the political ecologies of the Anthropocene through the prism of decoloniality.

\footnotetext{
${ }^{5}$ I acknowledge that the notion of indigeneity has been defined in various and often contradictory terms. For lack of a better word, I understand the expression 'indigenous' in the sense of a floating signifier. This means that the word indigenous as such is largely relational and devoid of any fixed political meaning, since it can be invoked by various individuals and interest groups. While some groups may genuinely self-identify with the term in a political sense, for example in the context of indigenous movements, others have critiqued or rejected it for a number of reasons. Some of these reasons are the delimitation of indigeneity to the local and the traditional, the performative use of the term in political debates, as well as the problematic juxtaposition of 'indigenous/traditional' and 'scientific' knowledge(s), for example in ecopolitical debates (see Pelican 2009).
} 
According to decolonial theorist Walter Mignolo, ideas of "de-colonial thinking and doing emerged from the sixteenth century on, as responses to the oppressive and imperial bent of modern European ideas projected to, and enacted in, the non-European world" (Mignolo 2009: 39). In this sense, coloniality is one of the constitutive elements of modernity - its "darker side" (see Mignolo 2000). There is no western modernity and progress without coloniality and its exploitative relations. Nevertheless, despite its critical take on the concept of modernity, decolonial thinking does not equate with postmodern or postcolonial theory. It differs from these intellectual traditions, because it attempts to de-link itself from the theoretical foundations of poststructuralism, postmodernity and postcolonial theory provided by intellectuals such as Michel Foucault, Jacques Lacan and Jacques Derrida as well as postcolonial thinkers such as Edward Said, Gayatri Spivak and Hommi Bhabha. As pointed out by Mignolo, the decolonial option is to practice epistemic disobedience and move away from the categories of occidental and Eurocentric thought to engage with ideas that have been marginalized and discredited as "traditional, barbarian, primitive, mystic" (this can be a difficult and frightening endeavor, to be sure) (Mignolo 2011: 46). In doing so, decolonial thinking relies on the theoretical foundations that have been established by scholars, artists and activists such as Enrique Dussel, Waman Puma de Ayala, Aimé Césaire, Frantz Fanon, Aníbal Quijano and Gloria Anzaldúa, among others (Mignolo 2007).

At the same time, decolonial thinking also differs from historical theories of decolonization, since it does not assume that colonialism has 'ended' and can thus be historicized. Decolonial theorists assert, rather, that contemporary forms of coloniality are perpetuated through globalization and imperialism. Coloniality, as opposed to colonialism, "refers to long-standing patterns of power that emerged as a result of colonialism, but that define culture, labor, intersubjective relations, and knowledge production well beyond the strict limits of colonial administrations" (Maldonado-Torres 2007: 243). In other words, the lived experience of epistemic (knowledge-related) as well as ontological (being-related) imperialism, for example in institutions of higher education, has directly influenced the lives and writing of many artists, scholars and activists who see themselves as being involved in an ongoing struggle against the existential and psychological violations of everyday coloniality (Anzaldúa 2015; Gutiérrez Rodríguez 2010).

In her seminal work titled Decolonizing methodologies, Linda Tuhiwai Smith (2006 [1999]: 20) emphasizes that a process of epistemic decolonization requires "a more critical understanding of the underlying assumptions, motivations and values that inform research practices." Based on such a critical understanding, a crucial step toward decolonizing the contemporary "geo-politics" and "body-politics" of knowledge is to take into account the locus of enunciation, that is, the geo-political and body-political location of the subject that speaks (Grosfóguel 2011: 4). In very concrete terms, this means that subjugated knowledges about ecological, economic, cultural-cognitive and spiritual transformations must be regarded as key points of reference for a decolonial option in the Anthropocene. Interpreted in such a way, decoloniality reaches beyond epistemic and scholarly concerns. It becomes a political commitment based on new forms of collaboration that are geared toward "studying with subaltern social groups," instead of merely perceiving them as subjects of research (Mato 2000: 487).

It is certainly interesting to note at this point that the diverse field of political ecology can be seen as an epistemological, geo-political and body-political project as well, because scholarship in political ecology sets out to "shatter comfortable and simplistic 'truths' about the relationship between society and its natural environment," and since it is often characterized by a normative commitment to analyzing unequal ecological exchange (Bridge et al. 2015: 5-8). ${ }^{6}$ Furthermore, as Enrique Leff points out, political ecology today is also directly concerned with both ontological and epistemological questions, since it critiques "the modes of thought, scientific paradigms, productive practices and social behavior that degrade life ... the power devices rooted in the hegemonic rationality of modernity" (Leff 2015: 64). Decolonial theorists would nonetheless argue that political ecology still adheres to research practices and paradigms that were mainly developed in the West (for instance Marxism or Actor-Network Theory), regardless of the internal diversity and dynamism of political ecology as a field of research. It is therefore crucial to ask how the conversation about 'global' politics and

\footnotetext{
${ }^{6}$ As Rebecca Lave (2015) argues, this focus on social structures and justice is less developed in strands of political ecology that are influenced by Actor-Network Theory (ANT).
} 
ethical responsibility under the emerging paradigm of the Anthropocene might benefit from a rapprochement between political ecology and decolonial thinking and doing.

\section{More-than-human political ecologies: a decolonial perspective}

In the time of omnipresent algorithms and globalized flows of commodities, technologies, bodies, services and virtual capital, together with a discernible shift in political power toward burgeoning economies, one can easily see that simplistic notions of clearly definable responsibilities in the Anthropocene have already morphed into a far more complex picture. This idea of complexity is most vividly expressed in the more-thanhuman aspects of the Anthropocene, where humans and nature are seen as essentially co-produced (Chagani 2014). Pondering 'our' collective responsibility in this newly proclaimed Human Age, we can only marvel at the rapid dissolution of fixed ontological boundaries between 'us' and our technological artefacts. The "Cartesian duality" of mind and body, and by extension of the argument, also our epistemic view of nature and culture as separate and independent realms seem to quickly dissolve in view of multiple reciprocal connections between materiality and social signification (Moore 2015a: 9). Scholars with an interest in political ecology, among others, have thus pointed to the complex intermingling of non-linear geological and cultural histories, suggesting that "the Enlightenment distinction between Nature and Society is obsolete" (Malm and Hornborg 2014: 62). Closely related to this line of reasoning is the idea that 'matter matters' or, put differently, the idea that entanglements of the human and the nonhuman, of organic and inorganic matter, are deeply enmeshed in the interdependent web of life, where they are gaining quasi-autonomous agency in their actual and virtual interactions.

One of the most influential intellectual traditions in the past two decades that has left its mark on how political ecologists engaged with the thought that various materialities are not inert or passive 'things' but rather vital, self-organizing, entangled and energetic, is the so-called new materialism. In the social sciences and humanities, the new materialism has found its diverse expressions in the works of scholars such as Bruno Latour, Manuel DeLanda, Jane Bennett, Karen Barad, Rosi Braidotti, Quentin Meillassoux, William E. Connolly, Donna Haraway and Brian Masumi, among others. Yet, despite the immense diversity of this body of work, there are some core ideas of new materialist thought that can be distilled. Broadly speaking, it can be asserted that the new materialism emerged as a reaction to the linguistic turn in philosophy and social theory. The overall goal of new materialist inquiry, on the one hand, is to overcome an overly narrow anthropocentric understanding of the human condition by projecting "variable degrees of subjectivity and agency well beyond the human estate, far into the biosphere"-thereby confirming the human subject as a real formation, while simultaneously erasing it as the "fundamental ground of all things" (Connolly 2013: 400, emphasis in the original). On the other hand, the new materialism also constitutes an attempt to recast dualistic demarcation lines between subject and object, nature and culture or the mental and the material in the light of a more-thanhuman ontology that "does not privilege some kinds of entity or agency over others and one in which new assemblages and unstable hybrids are recognised to be constantly emerging and dissipating across a normatively and ontologically horizontal plane" (Coole 2013: 454).

Yet, without necessarily succumbing to a naïve form of anthropocentric apologetics, it is still crucial to ask whether the pervasive idea of a 'more-than-human' life in the Anthropocene is already justified by accentuating the relevance of materiality and the need to respect the dignity of all living beings? Simply dismissing arguments for the notion of a shared humanity as being motivated by mere cultural reductionism, hidden agendas of white, male domination, or the desire to return to an idealized anthropocentric past is certainly problematic for a number of reasons. Even if such critiques are valid in light of the commendable intention to overcome human(ist) hubris, advocate for animal rights, and fight the various manifestations of structural violence, colonialism and racism, the main point, so I argue, is that conflating the notion of humanity with either materiality or technology may not simply result in greater humility and a heightened awareness for 'our' place in the interdependent web of life. Thinking in terms of more-than-human entanglements might simply replace the idea of an undifferentiated humanity with another abstract universal. The locus of political agency and 
responsibility for the Anthropocene condition, in other words, may be fundamentally obscured by the abstract complexity of socioecological and sociotechnological systems.

In response to charges of epistemic obscurantism and depoliticization, it has thus been proposed by new materialists to pay close attention to "the intensification, acceleration and globalisation of neoliberal capitalism", while simultaneously cultivating an ethics of care and human responsibility that "gives some priority to the human estate ... by emphasizing our manifold entanglements with nonhuman processes, both within the body and outside humanity" (Connolly 2013: 401-402, also see Coole 2013; Rekret 2016). This means precisely that preserving an analytical difference between humanity, ecology and technology is still recommendable, despite the physical mixing of these categories (Hornborg 2015: 58-59).

Moreover, if we are to reconsider more-than-human political ecologies from a decolonial perspective, it is important to note that the perpetuation of historically situated inequalities and power asymmetries is not merely the result of a ubiquitous anthropocentrism, as some followers of the new materialism would like to argue. It is also tightly linked to a "colonial western gaze which has objectified people living in the non-West, indigenous populations in colonized or formerly colonized nations and migrant groups in western societies" (McFarlane 2004: 175; emphasis added). By extension of the same argument, such a colonial/imperial mindset of objectification could well be the driving force behind the apparent neglect, appropriation and objectification of the biosphere, for example by perceiving 'it' as a mere resource or externality that is primarily defined through utilitarian value ascriptions. In short, the exclusive attention that is often given to problems of anthropocentrism or human exceptionalism rather obscures the historical fact that some humans have always been considered outside the realm of Society, and were thus perceived to be closer to an objectified and malleable Nature that is ready to be mastered, appropriated, and exploited. The Cartesian subject-object dualism and the distinction between Nature and Society, two features that are generally thought to be characteristic of modernity, have in fact often served as flexible political categories to justify the logic of coloniality. This colonial logic of selective objectification precisely means that relations between some people are subject to strategic "thing-ification" based on exclusionary categories such as race, color, language, gender, sexual orientation, etc. (Césaire 2000: 6). In the following section, I will therefore engage more thoroughly with the notion of objectification, and with the ambiguous political nature of objects.

\section{Ontology and the political ambiguity of objects}

The decolonial critique of coloniality/modernity as an epistemic and ontological configuration of social ordering and othering is indeed powerful. This fundamental critique certainly applies to political ecology as well, since the field is mostly rooted in western-centric concepts and research designs. Furthermore, some scholars have questioned the novelty of 'new' materialism as an analytical perspective within political ecology - as well as beyond. It has been argued, for example, that post- and decolonial scholarship have for a long time been critical of the "universality of the anthropocentric worldview that characterizes western scientific hegemony" (Willey 2016: 7). Moreover, it has been repeatedly pointed out that "Indigenous cultures ... have long recognized the vitality of all matter" (Schweitzer and Zerdy 2014: 6-7). Yet, as we shall see, there are still considerable differences between the meaning of spirituality in the context of indigenous cosmologies, and the largely secular "vital materiality" that is advocated by political ecologists such as Jane Bennett (2010: vii).

Before discussing these differences in greater detail, it is important first of all to engage in a more encouraging conversation, since political ecology still has a lot to contribute to the decolonial perspective on the relationship between power, knowledge and coloniality. On the one hand, political ecology shares the strong critique of modernity that is advanced by decolonial thinking, because it seeks to explore alternative and pluralist ways of being-in-the-world, while simultaneously deconstructing the very research designs, social structures, and cultural imaginaries upon which claims to ecopolitical 'truth' rest. On the other hand, it can be argued that the new materialism shares a common interest with decolonial critique as well, since it directs our attention toward 'that' which is objectified, muted, or rendered passive. This includes technological and other material formations as well as animals and "the multiple forces, process and properties of the earth itself" (Clark and Gunaratnam 2016: 16). In other words, by interrogating deceptively simple notions of 'things' that are rooted 
in clear subject-object divides, political ecology aims to illuminate the often troubling and contradictory dimensions of such objectifications.

As political ecologists and new materialists would argue, it is evident that the alleged borders between humans, nature and technology were quite fluid even before our ancestors used the first stone tools and wore animal skins to keep themselves warm. Hence it is suggested that even the analytical distinction between human and more-than-human 'agency' is very difficult to uphold in our contemporary "techno-cultures" (Cooper 2002), "techno-natures" (White and Wilbert 2009) or "nature-cultures" (Haraway 2003) that are all defined by the ceaseless mixing of human and the more-than-human (e.g. material, technological, metaphysical) aspects of being. Moreover, as Theodor W. Adorno (1962) reminds us, some analytical contradictions cannot simply be resolved by acquiring new (or different) forms of knowledge, for they are inherent to objects themselves. The object itself, in other words, may be fundamentally inaccessible to us by virtue of its intrinsic ambiguity.

In line with this argument, decolonial scholarship explicitly cautions against a totalizing view of ontology that aims to settle the question of what defines 'being' and its subject-object and human-nature relations in an authoritative manner. Certainly, there are many good reasons to be critical of a totalizing and essentializing interpretation of ontology that has been described by Eduardo Viveiros de Castro as a pervasive "philosophical war machine" (de Castro 2015: 2). A decolonial view on the fluid and contested boundaries between nature and humans, as well as between subject and object, would therefore imply a position of betweenness, referring to an ontology of "non-binary oscillation" or a constant movement within contradiction rather than between contradictory positions (Fry and Kalantidou 2014: 185). Thinking about the human condition in such terms means to acknowledge the geophysical agency of an internally differentiated humanity that is, at the same time, grounded in the mutual constitution of the human and the more-than-human, while neither category - the human as well as the more-than-human -is wholly reducible to the other. Consequently, this position implies to retain the subject/object dualism as a tool for critical analysis.

Put differently, assuming that our subjective experiences and relationships are first and foremost of a human quality, even if they are mediated experiences, does not necessarily compel us to draw totalizing teleological consequences from this condition. ${ }^{7}$ A decolonial ontology of non-binary oscillation would rather understand being as an openness that as such cannot ever be fully captured or defined by our knowledge about it, "only the nature of its happening(s) can be questioned" (Joronen and Häkli 2016: 14). ${ }^{8}$ In other words, positing that humans are in some way unique does not necessarily mean going down the slippery slope of human exceptionalism. Nothing prevents us from thinking about the human as unique and relational/historical, entangled in creative and productive exchanges with (equally unique) nonhuman or more-than-human forces, materialities, and other species. Consequently, we might have to abandon the notion of abstract universals such as humanity or more-than-humanity in favor of a more concrete universal, or - in the words of Aimé Césairea pluri-versal that is "rich with all particulars, the deepening and coexistence of all particulars" (as translated in Grosfóguel 2012: 95). Bearing in mind the immense problems that are implicated in the notion of the Anthropocene, this idea of pluriversality might then encourage us to engage more deeply with questions of ethics, value, and subject/object relations, while simultaneously prompting us to assess the coloniality of knowledge, being and power from the perspective of border thinking.

As opposed to conventional border studies that are often conducted from the universalizing zero-point perspective of western science and philosophy, border thinking can be defined as dwelling in the borderlands, metaphorically as well as in concrete material terms, to create new cultural and political imaginaries from a

\footnotetext{
${ }^{7}$ By using the term teleological, I refer to attempts at explaining the human condition and its various relations by reference to some absolute purpose, end, goal, or function.

${ }^{8}$ The necessity for retaining such a fundamental openness of being is motivated by the thought that "the human species ... is unthinkable in terms of one universal abstract that is good for everyone. Whomever holds such belief assumes truth without parenthesis and, therefore, war" (Gaztambide-Fernández 2014: 209). This is not to say that there are no ideologicalmaterial systems that assume a totalizing social logic and thus need to be analyzed in such terms, for example capitalism or communism. Pluriversality rather means to reject the view that such systems are identical with all of (bio)social life.
} 
position of being-in-between (Anzaldúa 1987). At the same time, border thinking also refers to a process of epistemic 'delinking' from modern and postmodern epistemologies. This process of epistemic delinking does not simply describe another critical project within western academia, a mere deconstruction of terminologies, but rather a delinking from a primarily western-centric epistemological frame that silences and subalternises non-western voices, knowledges, and languages within the totalising hierarchy of a single modernity (Gutierrez Rodriguez 2010, Mignolo 2007). This does not mean that border thinking is anti-scientific. Rather, it means that border thinking requires 'us' to practice "epistemic disobedience" by directing attention toward the ideological, geo-political, and body-political location of the subject that speaks (Mignolo 2011a). In this particular sense, border thinking seems to be a suitable approach for combining different aspects of political ecology and decoloniality with a pluriversal view of more-than-human ontologies.

When exploring the multiple entanglements of the Anthropocene through the lens of border thinking, it is nevertheless crucial to bear in mind that western industrialization and (neo)colonial appropriation are fundamentally linked to technological phenomena as well, epitomized by the invention of the steam engine and the building of railroad lines. Historically, the ideology of colonialism has always been tightly interwoven with modernist narratives about superior civilizational values and innovations that were allegedly transferred from Europe to its colonies, especially in the form of advanced industrial, military and medical technologies. At the same time, it is evident that technological progress in the West has been largely enabled by slavery, labor exploitation and colonial resource extraction, for example in the context of the Industrial Revolution of the late eighteenth century (Hornborg 2015: 60). However, I argue that it would be misleading to completely historicize the relationship between colonialism, capitalism and technology by suggesting that technological progress has nowadays become relatively more mundane or inclusive. On the contrary, technological progress today is still enabled by neocolonial appropriation and extractionism, exemplified by cheap labor and the commodification of the living environment which are, in turn, determining factors for the unfolding of globalized consumerism.

Considering how coloniality intersects with a global system of production, consumption, finance and labor that generates growing environmental degradation and social inequalities, it is nevertheless questionable whether the ethical attunement to matter that characterizes the new materialism is sufficient to fully account for these predicaments. When compared to the Marxian tradition of 'historical' materialism, the 'new' materialism does not take determination by the mode of production as its point of departure. Rather it positions itself in opposition to the 'linguistic turn' in social theory by arguing that questions of matter and materiality have been largely neglected by a supposedly dominant sociocentric constructivism that places disproportionate emphasis on language, discourse, and culture. The new materialism thus seeks to re-assert the primacy and agency of a vital, entangled, and self-organizing matter that is in constant flux and characterized by periods of relative equilibrium and radical disequilibrium (Bennett 2010; Connolly 2013). What is arguably at the heart of new materialist theory, which is indeed quite eclectic in its various manifestations, is the desire to overcome anthropocentric ways of thinking and doing, exemplified by the humanist subject/object or mind/matter divide, and by the tendency to treat 'nature' as a static exteriority.

The new materialism, for example as presented in the anthology New materialisms: ontology, agency, politics (Coole and Frost 2010) as well as in Jane Bennett's (2010) book Vibrant matter: a political ecology of things has nevertheless been criticized strongly in recent years, particularly by 'older' historical materialists who maintain that the new materialism's 'attentiveness to matter' bears striking semblance to the Marxian notion of fetishism. In other words, the new materialism supposedly mystifies objects of human labor by either setting them against, or elevating them above the human. As Marx himself writes:

"it is... precisely this finished form of the world of commodities - the money form-which conceals the social character of private labor and the social relations between the individual workers, by making those relations appear as relations between material objects, instead of revealing them plainly" (Marx 1867 [1990]: 168-169; emphasis added). 
In addition, it has been argued that Jane Bennett's 'vital materialism' is outwardly presenting itself as an approach that is open to 'spiritual' concerns, while remaining firmly rooted in a western-centric perspective that classifies animists as naïve Others who are "tainting the rationality of secular humans with the stain of 'premodern' magic" (Sundberg 2014: 37-38).

Nevertheless, William E. Connolly has recently engaged with some of this scorching critique from a new materialist perspective, arguing for a strong analytical focus on the workings of capitalism/neoliberalism, while proposing to take political action in the form of a cross-regional General Strike, which he refers to as an improbable necessity (Connolly 2015). Moreover, considering Jane Bennett's conclusion that it might be "worth running the risks associated with anthropomorphizing (superstition, the divinization of nature, romanticism)" an outright dismissal of new materialist thinking may even preclude a more fruitful exchange of arguments between new materialists and decolonial scholars (Bennett 2010: 120). To me at least, it seems more conducive to ask what specific risks we are talking about if we see anthropomorphism not as a naïve superstition, but as a fully legitimate way of knowing and being in the world? Contrary to Bennett, I would argue that the 'risks' of anthropomorphization should not be measured against the standards of a new materialist theory that juxtaposes 'naïve' forms of knowledge with the greater canon of modern science and western political thought, all while remaining largely silent about the epistemic, ethical, and civilizational privilege that it claims for itself. In this regard I agree with a growing body of scholarship that criticizes tendencies within new materialist theory to potentially reify colonial ways of knowing and being; to obscure the geo-historical embeddedness of knowledge by conflating being and our knowledge of it; and to underestimate the depoliticizing effects of distributing intentionality and responsibility across more-than-human "assemblages" (Gergan 2015; Rekret 2016; Sundberg 2014).

However, despite the ongoing debates about the presumably contentious aspects of new materialist theory, I still agree in part with Jane Bennett's (2001) interjection that the enchanted (anthropomorphic, spiritual, vitalist, animist, religious, sacred, ensouled, panpsychist, etc.) aspects of life are, if not risky, at least ambiguous for several reasons. This is not because of their numinous qualities or their alleged 'premodern irrationality' vis-á-vis the 'modern rational' way of knowing and being-in-the-world, but rather because of their concrete political implications that I will now bring into sharper relief.

\section{Enchantment and myth-making}

We do not need to recall large-scale geological processes, encounters with animals, or the fact that a network of nine radio telescopes will take the first ever picture of a black hole's event horizon in 2017, to realize that more-than-human nature is profoundly uncanny. This is especially true if we think of 'it' in terms of possessing a numinous quality, an innate capacity to sustain our bodily and spiritual existence, to communicate, interact and 'become' with us by inscribing an ambiguous syntax in our minds and on our bodies. If we accept this view, then a decolonial reading of political ecology requires us, among other things, to develop a heightened sense of enchantment, to engage more thoroughly with the mythical narratives that we tell us about ourselves and our relationships with the living or vital environment (at this point, one can already picture Marxist scholars sharpening their pencils, ready to denounce enchantment as a bourgeois reaction to alienating labor relations).

The decolonial notion of enchantment — which I am admittedly only able to briefly sketch here-is nevertheless rooted in the work of scholars, poets and activists such as Aimé Césaire and Gloria Anzaldúa. Enchantment, understood in this particular sense, does not mean to nurture new grandiose feelings of western Enlightenment romanticism. Neither does it mean advocating for a political theology of Gaia, nor to succumb to temptations of ethical relativism by regarding all ontological propositions as equally justified. Instead, the aim is to take a more modest approach that seeks to avoid the path-dependencies of institutionalized knowledge production by questioning the strictly policed boundaries of modern science and philosophy, which all too often are drawn according to exclusionary dualisms such as scientific vs. indigenous. While this approach may sound contradictory at first, it encourages a greater sensitivity for numinous, non-secular experiences and ways of being-in-the-world that are an integral part of how a great number of people give meaning to their lifeworlds. Nevertheless, it almost seems as if the secular impetus, which arguably dominates the natural sciences and much 
of contemporary social theory, has vigorously slammed the door shut on any serious attempt to begin a new conversation about the scientific 'demystification' of life.

Yet, if we choose to engage in such a conversation — and the 'we' that I am offering here is certainly an invitation to do so- it is important to realize that the modern demystification of our existence has never been a fait accompli (Latour and Davis 2015; Saler 2006). Then, does this insight imply that we should become even more modern? Or, in turn, that we should accept romanticized images of indigenous wisdom lock, stock, and barrel, so that the ecologically sensitive native finally becomes the new noble savage? Certainly not, although an overtly cynical and dismissive attitude toward indigenous spirituality mixed with anthropological cherrypicking does not seem to be a conducive approach either, especially if we come to realize that the coloniality of knowledge, being and power is a lived reality for many indigenous people. ${ }^{9}$ Such an experiential and affective gap is in fact deeply disturbing, and even more so, because for white, European scholars (like me) this gap also raises the serious question of whether we can, or should, speak about decoloniality at all? Where, we might ask, does appropriation begin?

Consequently, if you would ask me whether I enjoy the achievements of modern science and technology, then I must honestly say: "Yes, I do." I am writing this article on a computer, in a peaceful setting, in a capitalist country, near a supermarket. Still I realize that this situation is deeply connected to a system of consumption and production that relentlessly destroys the environment and forcibly denies the same privileges to precarious or 'subaltern' populations, while exploiting them economically, culturally, and in many other ways. There is everyday racism and discrimination. There is violence. But this is beside the point I am trying to make. The main point is that developing a genuinely decolonial perspective requires us to practice border thinking from our own point of view, and to delink ourselves from the hegemonic rationalities that are put in place to police the boundaries of modern scholarly discourse. This includes openly reclaiming our right to be enchanted, even if this means to (temporarily) leave the realm of scientific inquiry altogether, and engage in a very different conversation that is not limited to the epistemic and ontological territory of modernist discourses. As long as indigenous ways of knowing and being that are based on experience, art, language and ritual are marginalized within contemporary debates, this seems to be a 'risk' worth taking. As Rolando Vázquez (2011: 32) writes:

The expansion of modernity's epistemic territory relies on this manner of incorporation as erasure where there is a survival of written history and a loss of living memory, of memory as experience. Coloniality has performed this uprooting of the "non-western", this un-naming, in order to inscribe them in a system of classification as the other, the backward, the savage, the primitive other. Translation is here revealed as erasure.

Then, does the idea of enchantment imply that we should refrain from seeing ourselves as 'mere' scholars and strive to become better poets, artists and iconoclasts who unearth the salient myths that are connected to the notion of the Anthropocene? This is certainly one possibility, inasmuch as the latter suggestion leaves room for the important thought that we are constantly re-interpreting our various mythological traditions to make sense of the past and prepare for a vague future. However, this process of 'mythologization' that imparts the past, present and future with numinous qualities is neither a new cultural phenomenon, nor is it one that is exclusively linked to romantic fantasy or affect. As we shall see, enchantment also works as and through technology. The concrete enactment of differently rational, sensible, romantic, mythical and, in short, enchanted life worlds thus comes with its own mytho-politics that need to be illuminated as well if we wish to take pluriversality seriously, and seek to explore how the ideology of human mastery has developed historically (Schulz in press). Let me give a few brief examples:

\footnotetext{
${ }^{9}$ What I mean by 'anthropological cherry-picking' is the tendency to use isolated observations that are deeply rooted in western-centric epistemology and ontology to either totalize and romanticize indigenous spirituality, or to disavow it as being entirely motivated by political interest and some kind of ironic distance (for a discussion, see Willerslev 2013).
} 
In the aftermath of the famous battle of Kadesh that took place between the Egyptian and Hittite empires in $1274 \mathrm{BC}$ - one of the first military engagements for which a detailed contemporary account has been discovered - the Egyptian king Ramses II already knew too well how to rely on his scribes and artists to turn a rather indecisive military engagement abroad into a triumphant propaganda victory at home. In what could be described as the prototype of a modern public relations campaign, the king unified the rich faculties of expression that are inherent to spirituality, poetry, architecture and technology in a masterful way to craft an image of himself as a glorious victor and god-like ruler who single-handedly defeated the enemies of the realm on the battlefield. At the same time, Ramses 'The Great' understood that creating a mythical image of his eternal glory was not simply a matter of convincing his contemporaries, but a long-term project aimed at influencing future historic accounts. Seen in this light, history is always already a process of myth-making, of filling in the 'blank spots' and enchanting the past, often to reduce ambiguity and to tell more or less linear tales of human evolution.

From a decolonial point of view, the notion of enchantment thus invites us to examine how different narratives of human history are mythologized in the Anthropocene era. Who tells the grand narratives of human history in the Anthropocene? Who (and what) is included and excluded in the dominant 'myth-making' processes of our time? At close inspection, it seems as if modern science, politics and technology are not as rational and demystified as some may wish to believe. First of all, there is no doubt that organized religion continues to be a defining factor in societies all around the world. In addition, we find that some of the most iconic thinkers of western 'empirical' science were profoundly influenced by ideas of alchemy and mysticism, including Isaac Newton and Benjamin Franklin, as well as Francis Bacon, Erasmus Darwin and the "Romantic" scientists like Goethe and Novalis (Wilson 2004: 19). The relevance of these 'irrational' (or differently rational) undercurrents for today's rationalized and 'disenchanted' world, to finally paraphrase Max Weber, is of course debatable. While it seems wise to acknowledge that money and power are frequently implicated in holistic, spiritual, and esoteric affairs, it is still interesting to note that the paradigm of the 'living Earth' (not the ironic Latourian Gaia) is neither adequately described by the category of science, nor by the category of religion, which turns it into a very special form of border thinking vis-à-vis the more-than-human entanglements of the Anthropocene.

Beyond the confines of western (Greco-Roman, Judeo-Christian) cultural traditions - that are arguably far less 'western' and much more hybridized than purist ideas of culture are able to convey-we encounter a rich repertoire of mythical thought as well. Examples include indigenous traditions of animism and shamanism, 'African' art, philosophy and spirituality, as well as the mythical heritage of ancient Egypt, India, China, or Persia. ${ }^{10}$ In the Humanities, to use such a clumsy term for lack of a better word, one does not need to look very hard either to discover that an influential thinker like Gilles Deleuze readily confessed that he feels like a "pure metaphysician" (Villani 2007: 45). And who would deny that even a 'simple' technological artifact like a computer is quite an enigmatic machine for many of us - a state of affairs that regularly awakens millennialist visions and a whole range of technological anxieties, some of which seem to be rather unsubstantiated, while others appear to be more imminent. Luciano Floridi (2015: 10; emphasis added) comments:

The point is not that our machines are conscious, or intelligent, or able to know something as we do. They are not. The point is that they are increasingly able to deal with more and more tasks better than we do, including predicting our behaviors ... We are not at the center of the universe (Copernicus), of the biological kingdom (Darwin), or of the realm of rationality (Freud) ... Science is based on Big Data and algorithms, simulations and scientific networks, all aspects of an epistemology that is massively dependent on, and influenced by, information technologies. Conflicts, crime, and security have all been re-defined by the digital, and so has political power. In short, no aspect of our lives has remained untouched by the information revolution.

\footnotetext{
${ }^{10}$ Walter Mignolo (2002: 935) reminds us that the differentiation between, for example, African philosophy and philosophy as such is a clear expression of the western epistemic privilege, which characterizes modernity and the coloniality of power. It is also interesting to note that the cultural heritage of Egypt is seldom considered to be genuinely 'African'.
} 
Following this line of thought, we may conclude that older mythical elements re-emerge today as part of a digitalized and globalized epistemological fabric. Put differently, myths are not only the subject of the fine arts, cinema, video games or literature. Mythical references can be found everywhere, in the rationalized sphere of the political economy and technology as well as in debates about environmental politics. This rich mythical repertoire consists of narratives that have developed under specific historic, cultural and social circumstances, and are now incorporated into the globalized techno-capitalist system. Yet, examples of mythical 'incorporation' certainly abound. They range from the incorporation of the Greek pantheon into the Roman religion, to the gods, heroes, villains and tricksters that are now incorporated into the movies of the Hollywood industry. Moreover, there are numerous rituals and mythical references in politics and the economy that are used to legitimize hierarchies as well as contested claims to power, starting from the insignia and crowning of queens and kings to the 'bread and games' spectacles of popular culture that are used to ideologize consumerism.

This means precisely that a decolonial perspective of enchantment needs to be more than an act of mere mythologization, de-mythologization or re-mythologization. Simply speaking in mythical, numinous or metaphysical terms about ourselves or the living environment is not per se a decolonial position. Quite to the contrary. Mythical repertoires, as the example of Ramses II has shown, are as much an expression of genuine spirituality as they are of worldly power. And of course, they may be misused as technologies of enchantment to support various forms of dogmatism, extremism, exploitation, and coloniality (Gell 1992; Mignolo 2002). ${ }^{11}$ In addition to unjust economic relations, for example, there is also a clear trend toward cultural appropriation that can be observed with regard to the mythical imaginaries and experiences of indigenous peoples. Indigenous cosmologies, which encourage a greater harmony with the environment rather than its permanent appropriation, are frequently discarded as 'subaltern' forms of knowledge that have to be labeled and incorporated into the greater epistemic and ontological canon of modern technoscience. At the same time, there is a whole industry at work that turns indigenous philosophies into consumer products such as books, films or seminars, which often promote mere self-optimization, intellectual escapism, or esoteric kitsch. It is prudent to be politically mindful at this point. Indigenous ways of 'becoming-with' the environment are not meant to be calls for more 'conscious' geoengineering, the patenting of traditional medicine, or new green transformations led by the agrochemical industry. Questioning the material, epistemic and ontological fabric that 'we' have created - and that in turn has created a part of 'us' - necessarily means to question ourselves. Who are 'we' supposed to be after all, if we 'transform'?

\section{Together apart in a Promethean story?}

Prometheus, the ancient mythical figure who stole the fiery spark of artistic genius from the gods to give it to humankind, might indeed be a suitable metaphor for the salvation narratives of modern technoscience. The Promethean myth, as it has been first told by the Greek poet Hesiod, is nevertheless not a simple tale about a philanthropic liberator who acted on behalf of humankind. It is in fact a narrative about a cunning act of defiance that has brought upon humanity the curse of Pandora, who opened her infamous jar ( $\pi \dot{i} \theta$ os) to release all the evils of humanity - leaving only Hope inside. Accordingly, the story of Prometheus has been interpreted as a warning against the hubris of modern technoscience in various artistic works, ranging from Mary Shelley's novel Frankenstein to a recent movie titled Prometheus (2012), where the Promethean motive becomes a symbol for the human desire to unlock the mystery of its own existence by exploring outer space. Thus, the

\footnotetext{
${ }^{11}$ Alfred Gell differentiates between the technology of enchantment on the one hand, and the enchantment of technology on the other. The term technology of enchantment refers to technical activities such as art, ritual, music or architecture, which are used to express sacred or metaphysical qualities. The enchantment of technology, by contrast, means to imbue technical artifacts and activities as such with metaphysical qualities, for example cathedrals, paintings, dances, sculptures, or machines. This is an important distinction to make if we wish to understand how technology and enchantment are related to each other. Gell himself emphasizes that both processes may be (mis)used as techniques of power.
} 
Promethean motive serves as a useful example to show that the locus of mythical enunciation is never a nonplace (Mignolo 2002: 935). As previously mentioned, myths have always been (re)interpreted from a particular cultural perspective and symbolic tradition, which occasionally resulted in a return "to the premodern world as envisioned by the modern world," and even in uncanny rapprochements between romanticism, antimodernism and totalitarianism, particularly during the twentieth century (Ellwood 1999: 7; emphasis in the original).

Nevertheless, although myths might not be self-validating or universal in an essentialist sense, they are certainly able to cross and transcend boundaries and borders, precisely due to their wider symbolic and metaphorical adaptability. This is exactly the point where the decolonial notion of enchantment can help us to illuminate dichotomies such as spiritual/rational or nature/culture that pervade the dominant 'myth-making' processes of our time. Being mindful of the various ancestral traditions and symbolic forms of expression that we have inherited, we may better understand enchantment as an encounter with what the philosopher Henry Corbin calls the imaginal world, or mundus imaginalis. This imaginal world is not simply an 'imaginary' or a utopian fantasy, a wild image of the mind. Instead, it is seen as a realm of being rooted in both, the cognitive and cosmological function of the imagination. In the words of Corbin, it "provides the foundation for a rigorous analogical knowledge permitting us to evade the dilemma of current rationalism, which gives us only a choice between the two banal dualistic terms of either 'matter' or 'mind' ... ultimately, the 'socialization' of conscience is bound to replace the matter or mind dilemma by another no less fatal one, that of 'history' or 'myth'" (Corbin 1972: 7).

Enchantment, seen through the lens of border thinking, thus seeks to chart out a mediatory path that unites the sensory world, the sphere of intellect and the active imagination (mundus imaginalis) through a movement 'within' contradiction, rather than between contradictory positions. Such a perspective of border thinking might also help to perceive dualisms such as nature/culture, spirituality/rationality, modern/traditional, or history/myth in a different light. These dualisms are often portrayed as universal modes of thinking in contemporary scholarship, even though they still function as exclusionary devices of representation that are linked to western political, scientific, and philosophical traditions. Border thinking therefore takes as its point of departure "the experiences and views of the world and history of those whom Fanon calls les damnés de la terre ('the wretched of the earth,' those who have been, and continue to be, subjected to the standards of modernity)" (Mignolo 2005: 8). Such a critique does not only refer to a process of ideational delinking from western-centric discourses and epistemology. It is always already rooted in concrete materiality and experience, and therefore emerges primarily "from the body sensing the power differential of the border (any border, geopolitical and body-political)" (Gaztambide-Fernández 2014: 199).

\section{Toward a decolonial ecological critique}

The decolonial option that I have outlined in this article is rooted in the realization that multiple ways of being and knowing have always existed outside of the modern scientific worldview, which historically "came to define the very borders of the intelligible, of the 'real'" (Vázquez 2011: 36). Proposing a singular pathway toward an ecological critique in and of the Anthropocene that is rooted in decolonial thinking would thus run the risk of putting in place a formulaic approach that is complicit in obscuring the full range of these various perspectives. Instead, I have suggested that the decoloniality requires individuals to practice pensamiento fronterizo or "border thinking" from their own particular perspective (Saldívar 2006: 152). In many cases, this might mean to avoid simplistic either/or choices: "You either share the experience of the colonized, or you cannot possibly engage in decolonial/border thinking." ${ }^{12}$ How could a meaningful discussion about borders, coloniality and complex global entanglements - the First World in the Third, and the Third World in the First possibly emerge in view of such fundamentalisms? Decolonial ecological critique, I argue, must attempt to reach beyond many of these divisions, while still acknowledging that they do exist, and that we, as scholars, are often complicit in maintaining them. For many of us, and I explicitly include my white European self in this

\footnotetext{
12 This would mean to reify culturalism by regarding non-western identities as epistemically privileged. While this decision
} would be understandable in view of multiple (neo)colonial legacies, it also re-establishes old dichotomies. 
notion of 'us', decoloniality first of all means to listen carefully, and to accept the privilege of not being exposed to a variety of discriminatory experiences on a regular basis. It also means to learn how to make better use of this relative privilege, and to understand how to become a better ally to those who are directly exposed to the everyday realities of coloniality.

In this sense, decoloniality is as much about mutual learning and a different vision of 'becoming political' as it is about bridge-building and positions of 'betweenness' in order to spark a new conversation that enlivens the present. If the notion of decoloniality can teach us one thing, it is that the categories and language of western science and philosophy clearly reach their limits as soon as we are trying to describe the predicaments of our time. This is not about choosing sides. I would rather hope that more poets write about politics. I would also hope that the demmos finds new places to gather, to speak, and to listen. Yet, one may convincingly argue that the idea of a monolithic dēmos is fairly naïve. Does it not promote the ideal of citizenship, while ignoring the reality of who is considered a full citizen (or even human) in the present political and economic climate? In the words of Hannah Arendt, who has "the right to have rights, or the right ... to belong to humanity" (Arendt 1973 [1951]: 298)? Moreover, does the utopian notion of the dēmos not totalize the ideal of western liberal democracy - or Marxist humanism, depending on its interpretation - and therefore operate with categories of knowing and being that are inherently colonial? Does it not exclude animals and the living environment? Perhaps it does all of the above. Yet more importantly, these questions about 'becoming political' point us back to the earlier realization that the universalizing language and conventions of western-centric science and philosophy profoundly limit the scope of the Anthropocene conversation. The careful building of a pluriversal dialogue that is neither embedded in culturalism nor absolute particularism, but in the realization that multiple loci of enunciation coexist and are entangled through the coloniality of knowledge, being and power, will thus be the major task that lies ahead for a decolonial-ecological critique in and of the Anthropocene. While critical enchantment can help build such a pluriversal dialogue through creative processes of social transformation, and by shedding new light on supposedly universal ways of knowing and being-in-the-world, it is nonetheless worth remembering that power has always cast its own spell.

\section{References}

Adorno, T.W. 1962. Zur Logik der Sozialwissenschaften. Soziologische Schriften I. Frankfurt a. M.: Suhrkamp. Pp. 574-585.

Anzaldúa, G.E. 1987. Borderlands - la frontera. The new mestiza. First edition. San Francisco: Aunt Lute.

Anzaldúa, G.E. 2015. Light in the dark - luz en lo oscuro. Rewriting identity, spirituality, reality (edited by A. Keating). Durham: Duke University Press.

Arendt, H. 1973 [1951]. The origins of totalitarianism. San Diego, New York and London: Harcourt Inc.

Bennett, J. 2001. The enchantment of modern life: attachments, crossings, and ethics. Princeton: Princeton University Press.

Bennett, J. 2010. Vibrant matter: a political ecology of things. Durham: Duke University Press.

Bridge, G., J. McCarthy and T. Perreault 2015. Editors' introduction. In T. Perreault, G. Bridge and J. McCarthy (eds.) The Routledge handbook of political ecology. London: Routledge. Pp. 3-18.

Castree, N. 2015. Changing the Anthropo(s)cene: geographers, global environmental change and the politics of knowledge. Dialogues in Human Geography 5(3): 301-316.

Césaire, A. 2000. Discourse on colonialism. New York: Monthly Review Press.

Chagani, F. 2014. Critical political ecology and the seductions of posthumanism. Journal of Political Ecology 21: 424-436.

Clark, N. and J. Gunaratnam 2017. Earthing the Anthropos? From "socializing the Anthropocene" to geologizing the social. European Journal of Social Theory 20(1): 146-163.

Connolly, W.E. 2013. The "new materialism" and the fragility of things. Millennium: Journal of International Studies 41(3): 399-412. Researchgate 
Connolly, W.E. 2015. The fragility of things and a general strike. Theory \& Event 18(3).

Coole, D. 2013. Agentic capacities and capacious historical materialism: thinking with new materialisms in the political sciences. Millennium: Journal of International Studies 41(3): 451-469. Researchgate

Coole, D.H. and S. Frost 2010. New materialisms: ontology, agency, and politics. Durham, NC: Duke University Press.

Cooper, S. 2002. Technoculture and critical theory: in the service of the machine? London: Routledge.

Corbin, H. 1972. Mundus imaginalis, or the imaginary and the imaginal. Zürich and New York: Spring Press.

Crutzen, P.J. and E.F. Stoermer 2000. The "Anthropocene". IGBP Newsletter 41: 17-18.

Crutzen, P.J. and W. Steffen 2003. How long have we been in the Anthropocene? Climatic Change 61(3): 251257.

Dalby, S. 2016. Framing the Anthropocene: the good, the bad and the ugly. The Anthropocene Review 3(1) 3351.

De Castro, E.V. 2015. Who is afraid of the ontological wolf? Some comments on an ongoing anthropological debate. The Cambridge Journal of Anthropology 33(1): 2-17.

Du Prel, C. 1889. The philosophy of mysticism. London: George Redway.

Eiseley, L. 1970. The invisible pyramid. New York: Scribner.

Ernstson, H. and E. Swyngedouw. 2015. Rupturing the Anthro-obscene! The political promises of planetary and uneven urban ecologies. Position Paper. Conference at Teater Reflex 16-19 September, organized by KTH Environmental Humanities Laboratory, Stockholm.

Floridi, L. 2015. Singularitarians, AI-theists, and why the problem with artificial intelligence is H.A.L. (humanity at large), not HAL. APA Newsletter on Philosophy and Computers 14(2): 8-11. Academia

Fry, T. and E. Kalantidou. 2014. An exchange: questions from Tony Fry and Eleni Kalantidou and answers from Walter Mignolo. In T. Fry and E. Kalantidou (eds.) Design in the borderlands. London: Routledge. Pp. 173-188. Academia

Gaztambide-Fernández, R. 2014. Decolonial options and artistic/aestheSic entanglements: An interview with Walter Mignolo. Decolonization: Indigeneity, Education and Society 3(1): 196-212.

Gell, A. 1992. The technology of enchantment and the enchantment of technology. In J. Coote and A. Shelton (eds.). Anthropology, art and aesthetics. Oxford: Oxford University Press. Pp. 40-63.

Gergan, M.D. 2015. Animating the sacred, sentient and spiritual in post-humanist and material geographies. Geography Compass 9(5): 262-275. Academia

Grosfóguel, R. 2011. Decolonizing post-colonial studies and paradigms of political economy: transmodernity, decolonial thinking, and global coloniality. Transmodernity: Journal of Peripheral Cultural Production of the Luso-Hispanic World 1(1): 1-36.

Grosfóguel, R. 2012. Decolonizing western uni-versalisms: decolonial pluri-versalism from Aimé Césaire to the Zapatistas. Transmodernity: Journal of Peripheral Cultural Production of the Luso-Hispanic World 1(3): 88-103.

Gutiérrez Rodríguez, E. 2010. Decolonising postcolonial rhetoric. In E. Gutiérrez Rodríguez, M. Boatcă and S. Costa (eds.) Decolonizing European sociology: transdisciplinary approaches. Farnham: Ashgate. Pp. 49-70.

Haraway, D. 2003. The companion species manifesto: dogs, people, and significant otherness. Chicago: Prickly Paradigm Press.

Haraway, D. and M. Kenney. 2015. Anthropocene, Capitalocene, Chthulhucene: Donna Haraway in conversation with Martha Kenney. In H. Davis and E. Turpin (eds.) Art in the Anthropocene: encounters among aesthetics, politics, environments and epistemologies. London: Open Humanities Press. Pp. 255270.

Haraway, D., N. Ishikawa, G. Scott, K. Olwig, A.L. Tsing and N. Bubandt. 2016. Anthropologists are talking - about the Anthropocene. Ethnos: Journal of Anthropology 81:3: 535-564. 
Hornborg, A. 2015. The political ecology of the Technocene: uncovering ecologically unequal exchange in the world-system. In C. Hamilton, C. Bonneuil and F. Gemenne (eds.) The Anthropocene and the global environmental crisis. Rethinking modernity in a new epoch. London: Routledge. Pp. 57-69.

Joronen, M. and J. Häkli 2016. Politicizing ontology. Progress in Human Geography [online before print]. Pp. $1-19$.

Latour, B. and H. Davis. 2015. Diplomacy in the face of Gaia. Bruno Latour in conversation with Heather Davis. In H. Davis and E. Turpin (eds.) Art in the Anthropocene: encounters among aesthetics, politics, environments and epistemologies. London: Open Humanities Press. Pp. 43-56.

Lave, R. 2015. Reassembling the structural: political ecology and Actor-Network theory. In T. Perreault, G. Bridge and J. McCarthy (eds.) The Routledge handbook of political ecology. Abingdon and New York: Routledge. Pp. 213-223.

Leff, E. 2015. The power-full distribution of knowledge in political ecology: a view from the South. In T. Perreault, G. Bridge and J. McCarthy (eds.) The Routledge handbook of political ecology. Abingdon and New York: Routledge. Pp. 64-75.

Lövbrand, E., S. Beck, J. Chilvers, T.J. Forsyth, J. Hedrén, M. Hulme, R. Lidskog and E. Vasileiadou. 2015. Who speaks for the future of Earth? How critical social science can extend the conversation on the Anthropocene. Global Environmental Change 32: 211-218. Researchgate

Malm, A. and A. Hornborg. 2014. The geology of mankind? A critique of the Anthropocene narrative. The Anthropocene Review 1(1): 62-69. Researchgate

Marx, K. 1867 [1990]. Capital: a critique of political economy. Vol. 1. Trans. Ben Fowkes. New York: Penguin. Matthew, R.A. 2008. Resource scarcity: responding to the security challenge. International Peace Institute.

Mato, D. 2000. Not "studying the subaltern," but studying with "subaltern" social groups, or, at least, studying the hegemonic articulations of power. Nepantla: Views from South 1(3): 479-502.

McFarlane, K. 2004. Diaspora, cultural practice and syncretic visuality. Journal of Intercultural Studies 25(2): 175-184.

Maldonado-Torres, N. 2007. On the coloniality of being: contributions to the development of a concept. Cultural Studies 21(2-3): 240-270.

Mignolo, W.D. 2002. The enduring enchantment (or the epistemic privilege of modernity and where to go from here). South Atlantic Quarterly 101(4): 927-954.

Mignolo, W.D. 2005. The idea of Latin America. Oxford: Blackwell.

Mignolo, W.D. 2007. Delinking: the rhetoric of modernity, the logic of coloniality and the grammar of decoloniality. Cultural Studies 21(2-3): 449-514.

Mignolo, W.D. 2009. Coloniality: the darker side of modernity. In S. Breitwisser (ed.) Modernologies. Contemporary artists researching modernity and modernism. Barcelona: MACBA. Pp. 39-49.

Mignolo, W.D. 2011a. Epistemic disobedience and the decolonial option: a manifesto. Transmodernity: Journal of Peripheral Cultural Production of the Luso-Hispanic World 1(2): 44-66.

Mignolo, W.D. 2011b. The darker side of western modernity: global futures, decolonial options. Durham and London: Duke University Press.

Moore, J.W. 2015a. Nature in the limits to capital (and vice versa). Radical Philosophy 193: 9-19. Academia

Moore, J.W. 2015b. Putting nature to work: anthropocene, capitalocene, \& the challenge of world-ecology. In C. Wee, J. Schönenbach and O. Arndt (eds.) Supramarkt: A micro-toolkit for disobedient consumers, or how to frack the fatal forces of the Capitalocene. Gothenburg: Irene Books. Pp. 69-117. Researchgate

Morton, T. 2014. How I learned to stop worrying and love the term Anthropocene. The Cambridge Journal of Postcolonial Literary Inquiry 1(2), 257-264. Academia

Oldfield, F., A.D. Barnosky, J. Dearing, M. Fischer-Kowalski, J. McNeill, W. Steffen and J. Zalasiewicz. 2014. The Anthropocene review: its significance, implications and the rationale for a new transdisciplinary journal. The Anthropocene Review 1(1): 3-7. 
Olsson, L., A. Jerneck, H. Thoren, J. Persson and D. O'Byrne. 2015. Why resilience is unappealing to social science: theoretical and empirical investigations of the scientific use of resilience. Science Advances 1(4) [online].

Pelican, M. 2009. Complexities of indigeneity and autochthony: an African example. American Ethnologist 36(1): 52-65.

Pitman, A.J. 2005. On the role of geography in Earth System Science. Geoforum 36(2): 137-148. Researchgate

Rekret, P. 2016. A critique of new materialism: ethics and ontology. Subjectivity 9(3): 1-21. Academia

Rickards, L. 2015. Critiquing, mining and engaging Anthropocene science. Dialogues in Human Geography 5(3): 337-342. Researchgate

Rose, D.B. 2013. Anthropocene noir. Arena Journal 41/42: 206-219. draft

Ruddiman, W. 2013. The Anthropocene. Annual Review of Earth and Planetary Science 41: 45-68.

Saldívar, J.D. 2006. Border thinking, minoritized studies, and realist interpellations: the coloniality of power from Gloria Anzaldúa to Arundhati Roy. In L.M. Alcoff, M. Hames-García, S.P. Mohanty and P.M.L. Moya (eds.) Identity politics reconsidered. New York and Basingstoke: Palgrave Macmillan. Pp. 152170.

Saler, M. 2006. Modernity and enchantment: a historiographic review. American Historical Review 111(3): 692-716. Academia

Schulz, K. in press. Decolonising the Anthropocene: the mytho-politics of human mastery. In Woons, M. and S. Weier (eds.) Borders, borderthinking, borderlands: developing a critical epistemology of global politics. Bristol: E-International Relations Publishing. Academia

Schulz, K. and R. Siriwardane 2015. Depoliticized and technocratic? Normativity and the politics of transformative adaptation. Earth System Governance Paper No. 33. Lund and Amsterdam: Earth System Governance Project. Academia

Schweitzer, M. and J. Zerdy 2014. Introduction: object lessons. In Schweitzer, M. and J. Zerdy (eds.) Performing objects and theatrical things. Basingstoke: Palgrave Macmillan. Pp. 1-17.

Steffen, W., W. Broadgate, L. Deutsch, O. Gaffney and C. Ludwig. 2015. The trajectory of the Anthropocene: the great acceleration. The Anthropocene Review 2(1): 81-98.

Sundberg, J. 2014. Decolonizing posthumanist geographies. Cultural Geographies 21(1): 33-47. Researchgate

Swyngedouw, E. 2010. Apocalypse forever? Post-political populism and the spectre of climate change. Theory, Culture \& Society 27(2-3): 213-232.

Swyngedouw, E. 2011. Depoliticized environments: the end of nature, climate change and the post-political condition. Royal Institute of Philosophy Supplement 69: 253-274. Researchgate

Tilley, H. 2011. Africa as a living laboratory: empire, development, and the problem of scientific knowledge, 1870-1950. Chicago and London: The University of Chicago Press.

Todd, Z. 2015. Indigenizing the Anthropocene. In H. Davis and E. Turpin (eds.) Art in the Anthropocene: encounters among aesthetics, politics, environments and epistemologies. London: Open Humanities Press. Pp. 241-254.

Tuhiwai Smith, L. 2006 [1999]. Decolonizing methodologies: research and indigenous peoples. Ninth impression. London and New York: Zed Books.

Vázquez, R. 2011. Translation as erasure: thoughts on modernity's epistemic violence. Journal of Historical Sociology 24(1): 27-44.

Villani, A. 2007. 'I feel I am a pure metaphysician': the consequences of Deleuze's affirmation. In R. Mackey (ed.) Collapse: philosophical research and development Vol. III. Falmouth: Urbanomic. Pp. 45-62.

White, D.F. and C. Wilbert (eds.). 2009. Technonatures: environments, technologies, spaces, and places in the twenty-first century. Waterloo, ON: Wilfrid Laurier University Press.

Willerslev, R. 2013. Taking animism seriously, but perhaps not too seriously. Religion and Society: Advances in Research 4: 41-57. Academia 
Willey, A. 2016. A world of materialisms: postcolonial feminist science studies and the new natural. Science, Technology, and Human Values 41(6): 991-1014.

Wilson, P.L. 2004. The disciples at Saïs: a sacred theory of Earth. Capitalism Nature Socialism 15(2): 17-30.

All online resources have been last accessed on 22 September 2016. 